\title{
Metabolite production by species of Stemphylium
}

\author{
Olsen, Kresten Jon Kromphardt; Rossman, Amy; Andersen, Birgitte
}

Published in:

Fungal Biology

Link to article, DOI:

10.1016/j.funbio.2017.12.012

Publication date:

2018

Document Version

Peer reviewed version

Link back to DTU Orbit

Citation (APA):

Olsen, K. J. K., Rossman, A., \& Andersen, B. (2018). Metabolite production by species of Stemphylium. Fungal Biology, 122(2-3), 172-181. https://doi.org/10.1016/j.funbio.2017.12.012

\section{General rights}

Copyright and moral rights for the publications made accessible in the public portal are retained by the authors and/or other copyright owners and it is a condition of accessing publications that users recognise and abide by the legal requirements associated with these rights.

- Users may download and print one copy of any publication from the public portal for the purpose of private study or research.

- You may not further distribute the material or use it for any profit-making activity or commercial gain

- You may freely distribute the URL identifying the publication in the public portal

If you believe that this document breaches copyright please contact us providing details, and we will remove access to the work immediately and investigate your claim. 


\section{Accepted Manuscript}

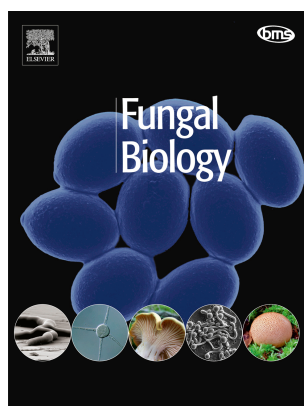

PII:

S1878-6146(18)30001-1

DOI:

10.1016/j.funbio.2017.12.012

Reference: $\quad$ FUNBIO 885

To appear in: Fungal Biology

Received Date: 14 November 2017

Revised Date: 18 December 2017

Accepted Date: 21 December 2017

Please cite this article as: Kromphardt Olsen, K.J., Rossman, A., Andersen, B., Metabolite production by species of Stemphylium, Fungal Biology (2018), doi: 10.1016/j.funbio.2017.12.012.

This is a PDF file of an unedited manuscript that has been accepted for publication. As a service to our customers we are providing this early version of the manuscript. The manuscript will undergo copyediting, typesetting, and review of the resulting proof before it is published in its final form. Please note that during the production process errors may be discovered which could affect the content, and all legal disclaimers that apply to the journal pertain. 


\section{Metabolite production by species of Stemphylium}

2

3 Kresten Jon Kromphardt Olsen*, Amy Rossman and Birgitte Andersen

4

5 First and third author: Department of Biotechnology and Biomedicine, Søltofts Plads Byg 223 and 221,

6 Danish Technical University, 2800 Kgs. Lyngby, Denmark; Second author: Department of Botany \&

7 Plant Pathology, Oregon State University, Corvallis, Oregon 97333.

8

9 * Corresponding author: K. J. K. Olsen; E-mail address: krjko@dtu.dk; Phone +45 22323517 10 


\section{Abstract}

12 Morphology and phylogeny has been used to distinguish members of the plant pathogenic fungal

13 genus Stemphylium. A third method for distinguishing species is by chemotaxonomy. The main goal of

14 the present study was to investigate the chemical potential of Stemphylium via HPLC-UV-MS analysis,

15 while also exploring the potential of chemotaxonomy as a robust identification method for

16 Stemphylium. Several species were found to have species-specific metabolites, while other species

17 were distinguishable by a broader metabolic profile rather than specific metabolites. Many previously

18 described metabolites were found to be important for distinguishing species, while some unknown

19 metabolites were also found to have important roles in distinguishing species of Stemphylium. This

20 study is the first of its kind to investigate the chemical potential of Stemphylium across the whole

21 genus.

23 Keywords:

24 Antibacterial metabolites, chemotaxonomy, host specific toxins, morphology, orobol, phytotoxins

\section{1. Introduction}

27 The fungal genus Stemphylium Wallr. consists of species that are pathogenic especially to members of 28 the legume family (Fabaceae) (Bradley et al. 2003), but also to asparagus, onion, garlic, parsley, pear, 29 sugar beet and tomato in various plant families (Gálvez et al. 2016; Graf et al. 2016; Hanse et al. 2015;

30 Köhl et al. 2009; Koike et al. 2013; Tanahashi et al. 2017). Some pathogenic fungal species have a

31 narrow host range, like S. Ioti on Lotus corniculatus or S. trifolii on Trifolium repens, while others have 
32 a broad range, such as S. vesicarium, which causes purple spot of asparagus and brown spot of pear

33 but is also able to live as a saprobe on plant debris (Graf et al. 2016; Köhl et al. 2009; Puig et al. 2015).

34 Some species, like S. botryosum, S. eturmiunum and S. vesicarium, can also occur on food products

35 such as beans, pulses, tomato, apple, pear and cereal grain (Pitt and Hocking 2009; Samson et al.

36 2010; Snowdon 1990). Though Stemphylium metabolites have been detected in mouldy tomatoes

37 (Andersen and Frisvad 2004), no mycotoxins sensu stricto have been associated with Stemphylium

38 food spoilage.

40 Morphologically, Stemphylium is easy to distinguish from its relatives, Alternaria Nees and Ulocladium

41 Preuss, by its percurrent or annellidic proliferation often with a distinct terminal swelling (Simmons

42 1967). Phylogenetically, the genus is also easy to delimit from Alternaria and Ulocladium (Ariyawansa

43 et al. 2015). Within Stemphylium some species such as S. botryosum and S. globuliferum or S.

44 eturmiunum and S. vesicarium appear similar and may be mixed up and misidentified using

45 morphology alone whereas some taxa previously recognized as distinct species such as S. alfalfa, S.

46 herbarum, S. vesicarium and others, fall in the same phylogenetic clade (Câmara et al. 2002;

47 Inderbitzin et al. 2009) and are now based on molecular data synonymized as S. vesicarium

48 (Woudenberg et al. 2017).

49

50 Chemically, individual Stemphylium strains have been shown to produce a broad variety of secondary

51 metabolites, of which many probably play a role during host plant infection as phytotoxins or host-

52 specific toxins (Trigos et al. 2011). Culture extracts of different strains of S. vesicarium have, for 
instance, been shown to be pathogenic to either European pear cultivars or Japanese pear cultivars,

54 but never both (Singh et al. 1999). The extracts contained host-specific toxins (SV-toxins I and II),

55 compounds that have not been structurally elucidated (Tanahashi et al. 2017). Other research has

56 shown that two endophytic strains of S. globuliferum produced alterporriols $\mathrm{H}$ and K, altersolanol L,

57 stemphypyrone (Debbab et al. 2009) and alterporriols D and E, altersolanol A (= stemphylin),

58 altersolanols B and C, and macrosporin (Liu et al. 2015), while an endophytic strain of S. botryosum

59 produced altersolanol A (= stemphylin), curvularin, dehydrocurvularin, macrosporin and

60 stemphyperylenol (Aly et al. 2010). Another study has shown a strain of S. herbarum (later identified

61 as Stemphylium sp. by Kurose et al. 2015) that produced alterporriols D-G and altersolanol A

62 (Kanamaru et al. 2012). Recently, it has also been shown that Stemphylium metabolites have

63 biological activities, such as cytotoxic and antibacterial effects (Debbab et al. 2009; Liu et al. 2015)

64 that may be of interest to the pharmaceutical industry.

66 Chemotaxonomy as reviewed by Frisvad et al. (2008) has only been attempted in a few cases on

67 Stemphylium (Andersen et al. 1995) and with little success. However, the study showed that S.

68 majusculum and some strains of S. botryosum produced stemphol (Andersen et al. 1995).

69 Chemotaxonomy has previously been useful in saprobic genera such as Aspergillus and Penicillium

70 (Kim et al. 2012; Kozlovskii et al. 2017) and host-specific plant pathogenic Alternaria (Andersen et al.

71 2008; Brun et al. 2013), but less successful in saprobic or non-pathogenic species of Alternaria

72 (Andersen et al. 2009) and Fusarium (de Kuppler et al. 2011). One purpose of this study was to

73 examine if profiles of secondary metabolites are species-specific according to the latest phylogeny 
74 (Woudenberg et al. 2017) and thereby would distinguish phylogenetically and/or morphologically

75 similar species. Another purpose was to examine if individual metabolites are associated with specific

76 host plants across species.

\section{2. Materials and methods}

792.1 Fungal strains

80 Eighty-seven Stemphylium strains were used in this study. Table 1 gives the identification numbers,

81 original and new identity, host and origin of these strains. The strains were selected to include as

82 many different species and habitats as possible and as many strains as possible that had been

83 investigated in previous studies (Câmara et al. 2002; Inderbitzin et al. 2009; Woudenberg et al. 2017).

84 An extended version of table 1 is available in supporting material table S1 giving strain numbers in

85 other collections and other papers.

86

2.2 Micro- and macro-morphological examination

88 All 87 strains were inoculated in 3 points on Potato Carrot Agar (PCA (Simmons 2007)), V8 juice agar

89 (V8 (Samson et al. 2010)), Potato Dextrose agar (PDA (Samson et al. 2010)) and Dichloran Rose Bengal

90 Yeast Extract Sucrose agar (DRYES (Samson et al. 2010)) and grown under standardized conditions

91 (Andersen et al. 2005; Simmons 2007). Selected strains were also inoculated on Spezieller

92 Nährstoffarmer Agar (SNA, Samson et al. 2010). The unsealed PCA, SNA and V8 plates (9 cm diameter,

93 plastic) were incubated in one layer for 7 days at $23^{\circ} \mathrm{C}$ under an alternating light/day cycle consisting

94 of $8 \mathrm{~h}$ cool-white fluorescent daylight and $16 \mathrm{~h}$ darkness. The lamps (TLD, 36W/95o, Philips, 
95 Amsterdam, Holland) were placed $40 \mathrm{~cm}$ from the plates. The DRYES and PDA plates $(9 \mathrm{~cm}$ diameter,

96 plastic) were placed in perforated plastic bags and incubated for 14 days in the dark at $25^{\circ} \mathrm{C}$. The

97 micro-morphological characteristics of the strains were observed from PCA and V8 plates after 7 days

98 of growth. Recording of primary conidiophore length, conidial size and shape (L/W ratio), colour and

99 ornamentation were done at X200 magnification using slide preparations made in Shear's mounting

100 liquid with clear Scotch tape as described in Samson et al. (2010). The PCA plates were then stored in

101 the dark at $7^{\circ} \mathrm{C}$ and checked for ascomata after 6 months. Colony characteristics (e.g. colour, texture

102 and diameter) were recorded from DRYES plates after 7 days of growth. The morphological

103 characteristics of each strain were registered and compared to reference strains.

104

\subsection{Chemical extraction}

106 The metabolite profiling was done on the 14-day-old DRYES and PDA cultures using a micro-scale

107 extraction method modified for Alternaria metabolites (Andersen et al. 2005). Five agar plugs (6 mm

108 ID) were cut from the two media and placed in a $2 \mathrm{ml} \mathrm{screw}$ top vial. Then $1.0 \mathrm{ml}$ ethyl

109 acetate/dichloromethane/methanol (3:2:1, vol/vol/vol) containing formic acid (1:100, vol/vol) was

110 added to each vial and the plugs were extracted by ultra-sonication for $60 \mathrm{~min}$. The extract was

111 transferred to a clean $2 \mathrm{ml}$ vial, evaporated to dryness in a gentle stream of $\mathrm{N}_{2}$ and re-dissolved in 400

$112 \mu \mathrm{l}$ methanol. The methanol extract was filtered through a $0.45 \mu \mathrm{m}$ filter into a clean $2 \mathrm{ml}$ vial and kept 113 at $-18^{\circ} \mathrm{C}$ prior to HPLC analysis. 
116 Analyses were performed using ultra-high-performance liquid chromatography (UPHLC) with a diode

117 array detector (DAD) and high-resolution maXis 3G QTOF mass spectrometer (MS) (Bruker Daltonics,

118 Bremen, Germany), equipped with an ESI source and connected to an Ultimate 3000 UHPLC system

119 (Dionex, Sunnyvale, CA, USA) equipped with a Kinetex 2.6- $\mu \mathrm{m}$ C18, $100 \mathrm{~mm} \times 2.1 \mathrm{~mm}$ column

120 (Phenomenex, Torrance, CA, USA) (Klitgaard et al. 2014). A linear water-acetonitrile gradient was used

121 (buffered with $20 \mathrm{mM}$ formic acid) starting from 15\% (vol/vol) acetonitrile and increased to $100 \%$ in

$12210 \mathrm{~min}$, maintained for 3 min before returning to the starting conditions. MS was performed in ESI+ in

123 the scan range $\mathrm{m} / \mathrm{z} 100-1250$, with a mass accuracy $<1.5 \mathrm{ppm}$ (Klitgaard et al. 2014). The mass

124 spectrum of sodium formate was used for calibration at the beginning (0.3-0.4 min) of each

125 chromatogram by injection with a divert valve. UV/VIS spectra were collected at wavelengths from

126200 to $700 \mathrm{~nm}$. Data processing was performed using DataAnalysis 4.0 and Target Analysis 1.2 (Bruker

127 Daltonics, Bremen, Germany) by the aggressive dereplication approach (Klitgaard et al. 2014), using a

128 database of 297 known and putative Alternaria and Stemphylium compounds, tentatively identifying

129 them based on accurate mass (deviation < $1.5 \mathrm{ppm}$ ) (Klitgaard et al. 2014) and if applicable an UV/VIS

130 spectrum. All major peaks observed in the base peak chromatograms, not tentatively identified by

131 this approach, were added to the search list of unknown compounds for mapping. All major peaks

132 (known and unknown) for the 87 extracts were subsequently ordered in a data matrix.

$134 \quad 2.5$ Data treatment and clustering

135 A binary matrix was constructed based on 87 strains and their production of 219 metabolites with 136 both known and unknown chemical structures. The presence or absence of a particular metabolite 
137 was scored as 1 or 0 , respectively, for each strain. The matrices were subjected to cluster analysis in

138 NTSYS-pc version 2.11N (Exeter software, Setauket, NY, USA). The binary metabolite matrix consisted

139 of no standardization, using Yule, Jaccard and Simple Matching similarity coefficients and Unweighted

140 Pair Group Method with Arithmetic mean (UPGMA) clustering method.

\section{3. Results}

1433.1 Taxonomy/Nomenclature and Morphology

144 The 87 Stemphylium strains used in this study were obtained from different fungal collections and the 145 original identification is given in Table 1 together with information on host and origin. Table 1 also 146 gives the new identification of individual strains based on our overall findings using morphology, 147 chemistry and names/synonyms proposed by Woudenberg et al. (2017). A supplementary table gives 148 all known identification numbers for each strain according to Câmara et al. (2002), Inderbitzin et al. 149 (2009) and Woudenberg et al. (2017). Sixteen species of Stemphylium are represented in this study.

151 Conidial measurements of selected Stemphylium cultures were conducted on strains grown on PCA, 152 SNA and V8 plates. The results show that conidial sizes in general were smallest on SNA and largest on 153 V8. Comparisons between SNA and PCA of three cultures show that conidia appeared paler in colour, 154 smoother and more ellipsoidal on SNA than on PCA (Fig. 1). Comparisons of PCA and V8 show that 155 most strains produced conidia that were darker and larger ( $5.9 \mu \mathrm{m}$ on average, 4.1 to $25.0 \mu \mathrm{m}$ ) and 156 wider (1.5 $\mu \mathrm{m}$ on average, 3.7 to $5.9 \mu \mathrm{m}$ ) on V8 compared to PCA. However, there was no pattern or 157 system concerning which species produced larger or smaller conidia. The L/W ratio also changed and 
158 most conidial shapes became more elongated on V8 compared to PCA, however, S. globuliferum, S.

159 loti and S. sarciniforme, maintained their L/W ratio best. Conidial size and L/W ratio varied within the

160 same culture and therefore the following conidial sizes are the maximum sizes on PCA. Conidial

161 measurements for all strains, except the two S. majusculum, were within the limits of the respective

162 species descriptions given in the literature (Câmara et al. 2002; Pei et al. 2011; Simmons 1969, 1985, 163 1989).

165 Common characteristics for S. callistephi, S. lancipes, S. lycopersici, S. majusculum and S. solani were 166 their pointed conidia, production of ascomata and L/W ratio ( $>1.9)$. Conidial size varied greatly from $16781 \times 25 \mu \mathrm{m}$ (S. lancipes), over $64 \times 24 \mu \mathrm{m}$ (S. callistephi) and $50 \times 21 \mu \mathrm{m}$ (S. solani) to $40 \times 18 \mu \mathrm{m}$ (S. 168 lycopersici). Stemphylium majusculum had a conidial size of 40-42 $\times 21-22 \mu \mathrm{m}$, an L/W ratio of 1.9 and 169 the presence of ascomata. Stemphylium trifolii also had pointed conidia and an L/W ratio of 2.0, but 170 much smaller $(25-28 \times 12-14 \mu \mathrm{m})$ and production of ascomata. Colony diameter on DRYES also varied 171 from 31-33 mm (S. majusculum), over $27 \mathrm{~mm}$ (S. callistephi) and $26 \mathrm{~mm}$ (S. lycopersici) to 21-16 mm 172 (S. solani), 16-22 $\mathrm{mm}$ (S. trifolii) and 10-12 $\mathrm{mm}$ (S. lancipes).

174 Stemphylium loti and S. sarciniforme had similar conidial size $(29-30 \times 22-23 \mu \mathrm{m}$ and 26-31 x 21-25 $175 \mu \mathrm{m}$, respectively), similar L/W ratio (1.3-1.4 and 1.1-1.3, respectively), lack of ascomata in culture and 176 grew slowly on DRYES (6-16 mm). Stemphylium globuliferum and S. gracilariae had conidial sizes of $177 \quad 20-27 \times 15-19 \mu \mathrm{m}$ and 21-28 x 13-16 $\mu \mathrm{m}$, respectively. Both species produced ascomata and had the 178 same L/W ratio (1.4-1.7) and diameter on DRYES (14-26 mm). 
180 With a few exceptions, the rest of the strains (62 in all) identified as S. astragali, S. beticola, S.

181 botryosum, S. eturmiunum, S. simmonsii, S. vesicarium (including former S. alfalfae and S. herbarum)

182 and strains with no species identification were more or less similar. Common for all of them was the

183 production of ascomata, conidial size of $24-45 \times 13-23 \mu \mathrm{m}$ (average: $31 \times 17 \mu \mathrm{m}$ ), L/W ratios between

1841.3 and 2.5 (average: 1.8), but no clear species segregation was seen. Figure 2 shows the morphology

185 of a selection of strains from this cluster. One of the exceptions was S. vesicarium \# 25 (ex-type

186 culture of S. herbarum (CBS 191.86)). It did not produce ascomata, produced only a few conidia and

187 was very restricted in its growth on DRYES.

\subsection{Chemistry}

190 The cluster analysis in Figure 3 is based on 219 secondary metabolites of both known and unknown

191 structure and shows that S. globuliferum, S. gracilariae, S. lancipes, S. loti, S. majusculum, S.

192 sarciniforme, S. solani and S. trifolii form their own distinct clusters based on the production of

193 species-specific metabolites or unique combinations of metabolites. However, several species were

194 not completely separated. Cluster 1 contains strains identified as S. botryosum, S. eturmiunum, S.

195 lycopersici and S. astragali, while Cluster 2 contains strains identified as S. callistephi, S. vesicarium

196 including strains originally identified as S. alfalfae and S. herbarum. Stemphylium strains in Cluster 2

197 and S. trifolii had the broadest metabolite profile producing between 72 and 93 detectable

198 metabolites, while S. lancipes and S. sarciniforme produced between 25 and 30 metabolites. 
200 Table 2 gives the production of the known metabolites by Stemphylium species with two or more

201 stains together with selected species-specific metabolites of unknown structure. Table 3 gives the 202 Mass $[\mathrm{M}+\mathrm{H}]$, putative formula and retention time (RT) for each of the unknown metabolites in Table 2032.

205 Stemphypyrone was the only known metabolite produced by all 87 strains, whereas only two of the 206 known metabolites, orobol and solanapyrone A, were species specific for S. trifolii and S. lancipes, 207 respectively. Stemphyperylenone A was specific to S. beticola and S. simmonsii. All known metabolites 208 could be detected in one or more strains in Clusters 1 and 2 and only strains in Cluster 2 had one 209 species/cluster specific metabolite of unknown structure (Uke23).

210 Four species, represented by only one strain each, are not shown in Table 2, but had the following

211 metabolite profiles: S. astragali produced alterporriol $\mathrm{G} / \mathrm{H}$, altersolanol $\mathrm{K} / \mathrm{L}$, macrosporin, stemphylin, 212 stemphyltoxins I to III and stemphyperylenol; S. callistephi produced altersolanol K/L, macrosporin, 213 stemphol, stemphylin, stemphyltoxins I to III and stemphyperylenol; S. lycopersici produced 214 macrosporin and stemphylin; and S. simmonsii produced GsS-1, stemphol, stemphyltoxins I to III and 215 stemphyperylenol. Stemphylium vesicarium \#25 (ex-type culture of S. herbarum CBS 191.86) is not

216 included in Cluster 2 in Table 2, because it produced only half of the metabolites that other S.

217 vesicarium and Stemphylium sp2 strains produced, which included alterporriol G/H, altersolanol K/L, 218 dehydrocurvularin, GsS-1, macrosporin, stemphol, stemphone, stemphylin, stemphyloxin I/II, 219 stemphyltoxins I to III and stemphyperylenol. 
222 Comparison between Stemphylium species and host (Table 1) did not give any strong connection 223 except between S. trifolii and Trifolium spp. In general Stemphylium species seem to be associated 224 with the pea family Fabaceae. A host/metabolite analysis did not show any associations between 225 particular metabolites (known as well as unknown) and host plant.

\section{4. Discussion}

\subsection{Taxonomy/Nomenclature and Morphology}

229 In recent years, several papers (Câmara et al. 2002; Inderbitzin et al. 2009; Köhl et al. 2009) have 230 suggested that S. alfalfae, S. herbarum and S. vesicarium together with other taxa represent the same 231 species based on molecular data. Our morphological and chemical results are in agreement.

232 Woudenberg et al. (2017) synonymised these species under the oldest name S. vesicarium (see 233 www.indexfungorum.org for all synonyms) and throughout the discussion S. vesicarium will also be 234 used for strains originally identified as S. alfalfae and S. herbarum.

236 Conidial measurements alone have always been problematic to use for identification of Stemphylium 237 species. Size and shape of the conidia can vary within the same culture depending on the age. Most 238 young Stemphylium conidia are small, spherical/ovoid, with one or few transverse septa. These 239 juvenile conidia become mature within a day or so, developing darker, multiseptate dictyoconidia and 240 assume the shape and size characteristic of its species. The medium also has an influence on conidial 241 size and shape. Our results show that growth on PCA, SNA and V8 yield quite different appearances 
242 (Fig. 1), which might contribute to the uncertainty of morphological identifications. For comparison, it

243 is important to use the same medium. In this study, we have used both PCA and V8 since both media

244 have been used in past descriptions (Simmons 1969, 1989, 2001). However, since SNA is a well-

245 defined medium compared to PCA and V8, experiments should be conducted to see if useful

246 characteristics are preserved on SNA, thus replacing PCA and V8.

248 Morphologically, species with oblong pointy conidia can be somewhat difficult to distinguish based on

249 measurements of conidia alone, but other characteristics make it possible to distinguish these

250 species. Strains of S. lancipes can be distinguished by their lanceolate, irregular conidia with several

251 transverse constrictions and often having secondary conidiophores that emerge from the apex of the

252 conidia. Stemphylium callistephi, S. lycopersici and S. solani are similar in conidial shape and size, but

253 other characteristics make them distinct. In this study, S. callistephi never produced secondary

254 conidia, while S. lycopersici grew secondary conidiophores, but only from the apex of the conidia and

255 S. solani produced secondary conidiophores from all cells of the conidial body. Also, S. lycopersici tend

256 to have a rectangular base compared to the other two species.

258 Based on conidial size alone S. trifolii is similar to S. eturmiunum, but S. trifolii have smooth, pointy, 259 regular dictyoconidia that are paler in colour, with one darker transverse septum and no prominent 260 constriction. Likewise, S. majusculum has conidia appearing similar to S. vesicarium, but their larger 261 size and slightly more rectangular shape make them distinguishable. The type strain of S. majusculum 262 (\# 36 = EGS 29-094) had smaller conidia $(43 \times 19 \mu \mathrm{m})$ in this study compared to the maxima $(64 \times 35$ 
$263 \mu \mathrm{m})$ given by Simmons (1969) in the original description, but similar dimensions to that $(49 \times 22 \mu \mathrm{m})$

264 reported by Câmara et al. (2002). We can offer no explanation for these findings.

266 As described by Graham (1953) S. loti can be distinguished from S. sarciniforme by the paler colour of

267 the conidia and conidiophores. The conidial shape of S. loti is similar to that of S. globuliferum, but

268 this species can be distinguished by the limited growth on PDA of $S$. loti $(15-30 \mathrm{~mm})$ compared to $S$.

269 globuliferum (41-69 mm). The conidia of S. beticola and S. simmonsii are similar to those of S.

270 globuliferum and S. loti and therefore other methods like phylogeny used by Woudenberg et al.

271 (2017) or chemotaxonomy should be used for distinguishing these species. Juvenile conidia of $S$.

272 gracilariae are often ellipsoidal compared with the subglobose juvenile conidia of S. globuliferum and

273 can be used to distinguish between the two species.

275 With the above described species S. vesicarium, S. botryosum, S. eturmiunum and other small-spored

276 Stemphylium remain to be given significant distinguishable morphological traits. This requires intense 277 expert knowledge, and therefore the distinguishing of these species should be done by other methods 278 than morphology, such as multi-locus phylogeny as described by Câmara et al. (2002), Inderbitzin et 279 al. (2009) and Woudenberg et al. (2017).

\subsection{Chemotaxonomy}

282 The results from this study show that metabolites alone are able distinguish most Stemphylium 283 species with the exception of S. botryosum and S. eturmiunum in Cluster 1 . Species that are only 
represented by one strain such as S. astragali, S. callistephi and S. lycopersici must be studied further with at least one other strain in order to find species-specific metabolites.

Our results show a distinct S. globuliferum cluster, containing the five strains (\#15 (CBS $716.68=$ EGS17-151), \#16 (FIP 108 = EGS 48-099), \#17 (FIP186), \#18 (FIP191), and \#19 (FIP220). However, the phylogenetical results of Woudenberg et al (2017) placed strains originally identified as $S$. globuliferum with S. simmonsii, since these strains did not form their own cluster. Two of those strains (\#15 and \#70 (FIP 227 = EGS 38-115 = CBS 133894)), which have been renamed S. simmonsii by

292 Woudenberg et al (2017), are also included in this study. One strain, \#15, clusters with four other $S$. 293 globuliferum strains, whereas \#70 clusters next to two S. beticola strains in our chemotaxonomy. This 294 discrepancy suggests that S. beticola, S. globuliferum and S. simmonsii are closely related, both 295 morphologically and molecularly, but not chemically. Strains of S. globuliferum produce stemphylin 296 and macrosporin, which neither S. beticola nor S. simmonsii do. Further molecular and chemical 297 analyses of the same material are needed in order to determine the true identity of these strains.

299 The metabolic profiles of Stemphylium seem to be more related to some of the large-spored, plant 300 pathogenic Alternaria species like A. porri and A. solani (Andersen et al. 2008) and Ulocladium 301 (Andersen and Hollensted 2008), than with the small-spored, saprobic Alternaria, such as A. alternata 302 (Polizzotto et al. 2012) and A. infectoria (Christensen et al. 2005). None of the Stemphylium strains 303 produced alternariols, altenuenes, tenuazonic acid or infectopyrones. Stemphypyrone is produced by 304 all strains as mentioned previously. It has only been isolated from one other genus of fungi, namely 
305 Exserohilum sp. (Li et al. 2014), and thus stemphypyrone can be used as a chemical marker for the 306 genus Stemphylium. Most of the known metabolites detected in this study (Table 2) have previously 307 been found in strains of Stemphylium. Our results show that the production of known metabolites is 308 not consistent in all stains of the same species (e.g. S. gracilariae) and often occurs in more than one 309 species (e.g. macrosporin). On the other hand, all species in Table 2 were able to produce species310 specific metabolites of unknown structure that could distinguish them from other species. Several 311 novel connections have been made. All four strains of $S$. loti produced pyrenophorin and 312 pyrenophorol, which are also produced by Phoma sp. and have antimicrobial activities (Zhang et al. 313 2008). All five strains of S. trifolii produced orobol, an isoflavone produced in red clover (Trifolium 314 pratense (Klejdus et al. 2001)), which is interesting, since all five strains were isolated from clover.

315 Stemphylium trifolii seems to be particularly adapted to Trifolium spp. in that both fungus and plant 316 produce orobol. Other species, like S. globuliferum and S. simmonsii, also isolated from Trifolium spp., 317 did not produce orobol. Two metabolites (Ukn185 and Ukn212) of unknown structure, but with 318 recognizable UV-spectra, mass and RT (Table 3), were produced in large quantities by S. beticola and

319 S. simmonsii. These two metabolites have previously been detected in species of Chalastospora as 320 metabolites 1010 and 1120, respectively (Andersen et al. 2009). Unknown metabolites with 321 phytotoxic activity have been reported from Stemphylium, such as SV- and SS-toxins (Zheng et al. 322 2010; Tanahashi et al. 2017), but no molecular information has been given, so direct comparison is 323 not possible. 
Metabolite profiling can be a powerful tool in fungal identification, but it has its limitations when it comes to strains that have been maintained and re-cultured for many years in culture collections. Our

327 strain of the ex-type culture of S. herbarum, \#25 (EGS 36-138 = CBS191.86), now S. vesicarium, has

328 stopped sporulating and is also losing its ability to produce metabolites. The same phenomenon has

329 been observed in Alternaria (Andersen et al. 2008). Only strains that can be unequivocally identified

330 morphologically should be used in the selection process of species-specific metabolites or

331 chemotaxonomic markers.

\subsection{Host specificity}

334 No connections were made between individual species and host plants. Some Stemphylium species,

335 such as S. globuliferum, S. sarciniforme and S. trifolii, were isolated from species of alfalfa, clover,

336 lentils, and pea (Table 1). Other species/taxa, like S. eturmiunum, S. vesicarium and Stemphylium sp.

337 2, have a broader host range comprising Amaryllidaceae, Apiaceae, Brassicaceae, Poaceae, Rosaceae

338 and Solanaceae (Table 1). A search in U.S. National Fungus Collections shows that the species S.

339 vesicarium (including S. alfalfae and S. herbarum) will have an extremely broad host range (Farr and 340 Rossman 2017). One reason that a species can have such a broad host range could be that all strains 341 produce that same non-host-specific metabolites. Trigos et al. (2011) proposed that macrosporin is a 342 non-host specific toxin that plays a role in leaf necrosis due to its photosensitizing ability. Since 343 macrosporin is a non-species-specific metabolite produced by $58(67 \%)$ of the tested strains, this 344 metabolite might be a contributing factor to the broad host range of Stemphylium, especially among 345 S. botryosum and S. vesicarium. It may also explain why one strain can be pathogenic to several, very 
346 different host plants. Neergaard (1945) tested the pathogenicity of several strains of S. botryosum and

347 found that they had a broad host range attacking cabbage, carrot, lettuce, onion, pea, tomato,

348 Dianthus and Godetia, but neither wheat nor cucumber. Similarly, strains of S. lycopersici have shown

349 to have a broad host range (Nasehi et al. 2014) being pathogenic to tomato, eggplant, pepper and

350 lettuce, regardless of original host. However, none of the S. lycopersici strains were pathogenic to

351 cabbage (Nasehi et al. 2014).

\section{5. Conclusion}

354 The chemical potential of the genus Stemphylium is broad as numerous unknown compounds have 355 been found in this study. The chemotaxonomic investigation of the whole genus revealed 356 distinguishable characteristics for most of the included species, while a subset of the investigated 357 strains produced similar metabolic profiles. Our chemotaxonomic study supports the phylogenetically 358 based findings by Woudenberg et al. (2017) who proposed to synonymize S. alfalfae, S. herbarum, S. 359 vesicarium and others into $S$. vesicarium. The results from this study show that at least two to four 360 strains of a species are necessary to give diverging branches in the chemotaxonomy. Therefore, future 361 chemotaxonomic investigations should include more species and more strains from some of the 362 investigated species, such as S. astragali, S. callistephi and S. lycopersici. Also, as presented here, a 363 solid group of a single species can identify species-specific metabolites, which can be used for 364 identification. Furthermore, investigation and comparison of conidial morphology showed differences 365 in conidial size from the same strain, when comparing conidia from different media. Thus, the 366 cultivation conditions have implications when comparing results to described reference strains. 


\section{6. Acknowledgement}

369 We would like to thank Kristian Fog Nielsen for technical and analytical assistance while conducting 370 HPLC-UV-MS analysis. 


\section{References}

Aly AH, Debbab A, Edrada-Ebel RA, Müller WEG, Kubbutat MHG, Wray V, Ebel R, Proksch P, 2010. Protein kinase inhibitors and other cytotoxic metabolites from the fungal endophyte Stemphylium botryosum isolated from Chenopodium album. Mycosphere 1: 153-162.

Andersen B, Frisvad JC, 2004. Natural occurrence of fungi and fungal metabolites in moldy tomatoes. Journal of agricultural and food chemistry 52: 7507-7513.

Andersen B, Dongo A, Pryor BM, 2008. Secondary metabolite profiling of Alternaria dauci, A. porri, A. solani, and A. tomatophila. Mycological Research 112: 241-250.

Andersen B, Hollensted M, 2008. Metabolite production by different Ulocladium species. International journal of food microbiology 126: 172-179.

Andersen B, Hansen ME, Smedsgaard J, 2005. Automated and unbiased image analyses as tools in phenotypic classification of small-spored Alternaria spp. Phytopathology 95: 1021-1029.

Andersen B, Solfrizzo M, Visconti A, 1995. Metabolite profiles of common Stemphylium species. Mycological Research 99: 672-676.

Andersen B, Sørensen JL, Nielsen KF, Gerrits van den Ende B, de Hoog S, 2009. A polyphasic approach to the taxonomy of the Alternaria infectoria species-group. Fungal Genetics and Biology 46: 642-656.

Ariyawansa HA, Thambugala KM, Manamgoda DS, Jayawardena R, Camporesi E, Boonmee S, Wanasinghe DN, Phookamsak R, Hongsanan S, Singtripop C, Chukeatirote E, Kang JC, Gareth Jones EB, Hyde KD, 2015. Towards a natural classification and backbone tree for Pleosporaceae. Fungal Diversity 71: 85-139. 
Bradley DJ, Gilbert GS, Parker IM, 2003. Susceptibility of clover species to fungal infection: the interaction of leaf surface traits and environment. American Journal of Botany 90: 857-864.

Brun S, Madrid H, Van Den Ende BG, Andersen B, Marinach-Patrice C, Mazier D, De Hoog GS, 2013. Multilocus phylogeny and MALDI-TOF analysis of the plant pathogenic species Alternaria dauci and relatives. Fungal Biology 117: 32-40.

Câmara MP, O'Neill NR, Van Berkum P, 2002. Phylogeny of Stemphylium spp. based on ITS and glyceraldehyde-3-phosphate dehydrogenase gene sequences. Mycologia 94: 660-672.

Christensen KB, Van Klink JW, Weavers RT, Larsen TO, Andersen B, Phipps RK, 2005. Novel chemotaxonomic markers of the Alternaria infectoria species-group. Journal of agricultural and food chemistry 53: 9431-9435.

de Kuppler ALM, Steiner U, Sulyok M, Krska R, Oerke EC, 2011. Genotyping and phenotyping of Fusarium graminearum isolates from Germany related to their mycotoxin biosynthesis. International Journal of Food Microbiology 151: 78-86.

Debbab A, Aly AH, Edrada-Ebel R, Wray V, Müller WE, Totzke F, Zirrgiebel U, Schächtele C, Kubbutat MHG, Lin WH, Mosadak M, Hakiki A, Proksch P, Ebel R, 2009. Bioactive metabolites from the endophytic fungus Stemphylium globuliferum isolated from Mentha pulegium. Journal of Natural Products 72: 626-631.

Farr DF, Rossman AY, 2017. Fungal Databases, U.S. National Fungus Collections, ARS, USDA. Retrieved October 6, 2017, from https://nt.ars-grin.gov/fungaldatabases/

Frisvad JC, Andersen B, Thrane U, 2008. The use of secondary metabolite profiling in chemotaxonomy of filamentous fungi. Mycological Research 112: 231-240. 
414 Gálvez L, Gil-Serna J, García M, Iglesias C, Palmero D, 2016. Stemphylium leaf blight of garlic (Allium sativum) in Spain: taxonomy and in vitro fungicide response. The Plant Pathology Journal 32: 388-395.

Graf S, Bohlen-Janssen H, Miessner S, Wichura A, Stammler G, 2016. Differentiation of Stemphylium vesicarium from Stemphylium botryosum as causal agent of the purple spot disease on asparagus in Germany. European Journal of Plant Pathology 144: 411-418.

Graham JH, 1953. A disease on Birdsfoot Trefoil caused by a new species of Stemphylium. Phytopathology 43: 577-579.

Hanse B, Raaijmakers EEM, Schoone AHL, Van Oorschot PMS, 2015. Stemphylium sp., the cause of yellow leaf spot disease in sugar beet (Beta vulgaris L.) in the Netherlands. European Journal of Plant Pathology 142: 319-330.

Inderbitzin P, Mehta YR, Berbee ML, 2009. Pleospora species with Stemphylium anamorphs: a fourlocus phylogeny resolves new lineages yet does not distinguish among species in the Pleospora herbarum clade. Mycologia 101: 329-339.

Kanamaru S, Honma M, Murakami T, Tsushima T, Kudo S, Tanaka K, Nihei KI, Nehira T, Hashimoto M, 2012. Absolute stereochemistry of altersolanol A and alterporriols. Chirality 24: 137-146. Penicillium species ( $P$. echinulatum, $P$. expansum, $P$. solitum, and $P$. oxalicum) and its correlation with antioxidant activity. Journal of Microbiological Methods 90: 327-335. 
Klejdus B, Vitamvásová-Štěrbová D, Kubáň V, 2001. Identification of isoflavone conjugates in red clover (Trifolium pratense) by liquid chromatography-mass spectrometry after two-dimensional solid-phase extraction. Analytica Chimica Acta 450: 81-97.

Klitgaard A, Iversen A, Andersen MR, Larsen TO, Frisvad JC, Nielsen KF, 2014. Aggressive dereplication using UHPLC-DAD-QTOF: screening extracts for up to 3000 fungal secondary metabolites. Analytical and Bioanalytical Chemistry 406: 1933-1943.

Köhl J, Groenenboom-de Haas B, Goossen-van de Geijn H, Speksnijder A, Kastelein P, de Hoog S, van den Ende BG, 2009. Pathogenicity of Stemphylium vesicarium from different hosts causing brown spot in pear. European Journal of Plant Pathology 124: 151-162.

Koike ST, O'Neill N, Wolf J, Van Berkum P, Daugovish O, 2013. Stemphylium leaf spot of parsley in California caused by Stemphylium vesicarium. Plant Disease 97: 315-322.

Kozlovskii AG, Antipova TV, Zhelifonova VP, Baskunov BP, Ivanushkina NE, Kochkina GA, Ozerskaya SM, 2017. Secondary metabolites of fungi of the Usti section, genus Aspergillus and their application in chemosystematics. Microbiology 86: 176-182.

Kurose D, Misawa T, Suzui T, Ichikawa K, Kisaki G, Hoang LH, Furuya N, Tsuchiya K, Tsushima S, Sato T, 2015. Taxonomic re-examination of several Japanese Stemphylium strains based on morphological and molecular phylogenetic analyses. Journal of General Plant Pathology 81: 358367.

Laatsch H. AntiBase 2010. Wiley-VCH: Weinheim, Germany, 2010.

Li R, Niu S, Guo L, Zhang Y, 2014. Two new pyrone derivatives from the plant endophytic fungus Exserohilum sp. Natural Products Communications 9: 1497-1498. 
Liu Y, Marmann A, Abdel-Aziz MS, Wang CY, Müller WE, Lin WH, Mándi A, Kurtán T, Daletos G, Proksch, P, 2015. Tetrahydroanthraquinone derivatives from the endophytic fungus Stemphylium globuliferum. European Journal of Organic Chemistry 2015: 2646-2653.

Nasehi A, Kadir JB, Nasr-Esfahani M, Abed-Ashtiani F, Wong MY, Rambe SK, Golkhandan E, 2014. Analysis of genetic and virulence variability of Stemphylium lycopersici associated with leaf spot of vegetable crops. European Journal of Plant Pathology 140: 261-273.

Neergaard P, 1945. Danish species of Alternaria and Stemphylium. Oxford university press, London, UK.

Pei Y, Wang Y, Geng Y, O’Neill N, Zhang X, 2011. Three novel species of Stemphylium form Sinkiang, China: Their morphological and molecular characterization. Mycological Progress 10: 163-173.

Pitt JI, Hocking AD, 2009. Fungi and food spoilage. Springer, New York, USA.

Polizzotto R, Andersen B, Martini M, Grisan S, Assante G, Musetti R, 2012. A polyphasic approach for the characterization of endophytic Alternaria strains isolated from grapevines. Journal of Microbiological Methods 88: 162-171.

Puig M, Ruz L, Montesinos E, Moragrega C, Llorente I, 2015. Combined morphological and molecular approach for identification of Stemphylium vesicarium inoculum in pear orchards. Fungal Biology 119: 136-144.

Samson RA, Houbraken J, Thrane U, Frisvad JC, Andersen B, 2010. CBS laboratory manual series 2 Food and indoor fungi. CBS Fungal Biodiversity Centre, Utrecht, The Netherlands.

Simmons EG, 1967. Typification of Alternaria, Stemphylium, and Ulocladium. Mycologia 59: 67-92.

Simmons EG, 1969. Perfect states of Stemphylium. Mycologia 61: 1-26. 
475 Simmons EG, 1985. Perfect states of Stemphylium II. Sydowia 38: 284-293.

476 Simmons EG, 1989. Perfect states of Stemphylium III. Memoirs of the New York Botanical Garden 49:

$477 \quad 305-307$.

478 Simmons EG, 2001. Perfect states of Stemphylium-IV. Harvard Papers in Botany 6: 199-208.

479 Simmons EG, 2007. Alternaria - an identification manual. CBS Fungal Biodiversity Centre, Utrecht, The $480 \quad$ Netherlands.

481 Singh $\mathrm{P}$, Bugiani R, Cavanni $\mathrm{P}$, Nakajima H, Kodama M, Otani H, Kohmoto K, 1999. Purification and 482 biological characterization of host-specific SV-toxins from Stemphylium vesicarium causing 483 brown spot of European pear. Phytopathology 89: 947-953.

484 Smedsgaard J, 1997. Micro-scale extraction procedure for standardized screening of fungal metabolite 485 production in cultures. Journal of Chromatography A 760: 264-270.

486 Snowdon AL, 1990. A colour atlas of post-harvest diseases and disorders of fruits and vegetables.

$487 \quad$ Volume 1: General Introduction and Fruits. Wolfe Scientific Ltd., London, UK.

488 Tanahashi M, Okuda S, Miyazaki E, Parada RY, Ishihara A, Otani H, Osaki-Oka K, 2017. Production of 489 host-selective SV-toxins by Stemphylium sp. Causing Brown Spot of European Pear in Japan. $490 \quad$ Journal of Phytopathology 165: 189-194.

491 Trigos Á, Mendoza G, Espinoza C, Salinas A, Fernández JJ, Norte M, 2011. The role of macrosporin in 492 necrotic spots. Phytochemistry Letters 4: 122-125.

493 Woudenberg JHC, Hanse B, van Leeuwen GCM, Groenewald JZ, Crous PW, 2017. Stemphylium $494 \quad$ revisited. Studies in Mycology 87: 77-103. 
495 Zhang W, Krohn K, Egold H, Draeger S, Schulz B, 2008. Diversity of antimicrobial pyrenophorol 496 derivatives from an endophytic fungus, Phoma sp. European Journal of Organic Chemistry 2008: $497 \quad 4320-4328$.

498 Zheng L, Lv R, Huang J, Jiang D, Hsiang T, 2010. Isolation, purification, and biological activity of a 499 phytotoxin produced by Stempyhlium solani. Plant Disease. 94: 1231-1237. 500 501 502 503 
504 Table 1. Stemphylium strains used in this study with original and new name, host and country of 505 origin.

\begin{tabular}{|c|c|c|c|c|c|}
\hline Analysis \# & ID \# ${ }^{\mathrm{a}}$ & New names ${ }^{b}$ & Original names $^{c}$ & Host & Origin \\
\hline 1 & CBS 192.86* & S. vesicarium & S. alfalfae T & Medicago sativa & Australia \\
\hline 2 & FIP 151* & S. vesicarium & S. alfalfae & Medicago sativa & USA \\
\hline 3 & FIP $152 *$ & S. vesicarium & S. alfalfae & Medicago sativa & USA \\
\hline 4 & FIP 149 & S. astragali & S. astragali & Astragalus sinicus & Japan \\
\hline 5 & CBS 714.68* & S. botryosum & S. botryosum & Medicago sativa & Canada \\
\hline 6 & FIP 112 & S. botryosum & S. botryosum & Medicago sativa & New Zealand \\
\hline 7 & FIP 166 & S. callistephi & S. callistephi & Callistephus chinensis & USA \\
\hline 8 & FIP 080 & S. eturmiunum & Stemphylium sp. & Brassica oleracea & USA \\
\hline 9 & FIP 109 & S. eturmiunum & S. eturmiunum & Vicia sativa & New Zealand \\
\hline 10 & FIP 266 & S. eturmiunum & Stemphylium sp. & - & India \\
\hline 11 & IBT 8213 & S. eturmiunum & S. eturmiunum & Hordeum vulgare & Denmark \\
\hline 12 & IBT 8224 & S. eturmiunum & S. eturmiunum & Brassica napus & Italy \\
\hline 13 & IBT 8231* & S. eturmiunum & S. eturmiunum & Solanum lycopersicum & Greece \\
\hline 14 & IBT 40618 & S. eturmiunum & S. eturmiunum & Capsicum annuum & Denmark \\
\hline 15 & CBS 716.68* & S. globuliferum & S. globuliferum & Commelina sp. & USA \\
\hline 16 & FIP 108 & S. globuliferum & Stemphylium sp. & Medicago lupulina & New Zealand \\
\hline 17 & FIP 186 & S. globuliferum & S. botryosum & Medicago sativa & USA \\
\hline 18 & FIP 191 & S. globuliferum & Stemphylium sp. & Trifolium repens & USA \\
\hline 19 & FIP 220 & S. globuliferum & Stemphylium sp. & Trifolium repens & USA \\
\hline 20 & CBS 482.90* & S. gracilariae & S. gracilariae T & Gracilaria sp. & Israel \\
\hline 21 & FIP 001 & S. gracilariae & Stemphylium sp. & - & USA \\
\hline 22 & FIP 003 & S. gracilariae & Stemphylium sp. & - & USA \\
\hline 23 & FIP 084 & S. gracilariae & Stemphylium sp. & Brassica napus & Italy \\
\hline 24 & IBT 8227 & S. gracilariae & Stemphylium sp. & Brassica napus & Italy \\
\hline 25 & CBS 191.86* & S. vesicarium & S. herbarum T & Medicago sativa & India \\
\hline 26 & FIP 015 & Stemphylium sp. 1 & Stemphylium sp. & Pisum sativum & New Zealand \\
\hline 27 & FIP 023 & Stemphylium sp. 1 & Stemphylium sp. & Daucus carota & New Zealand \\
\hline 28 & FIP 184 & Stemphylium sp. 2 & Stemphylium sp. & Medicago sativa & New Zealand \\
\hline 29 & CBS 101217* & S. lancipes & S. lancipes & Aquilegia sp. & New Zealand \\
\hline 30 & FIP $153^{*}$ & S. lancipes & S. Iancipes T & Aquilegia sp. & New Zealand \\
\hline 31 & FIP 162 & S. loti & S. loti & - & - \\
\hline 32 & FIP 174 & S. loti & S. loti & Lotus corniculatus & USA \\
\hline 33 & FIP 175 & S. loti & S. loti & Lotus corniculatus & USA \\
\hline 34 & FIP 217 & S. loti & Stemphylium sp. & - & - \\
\hline 35 & FIP 156* & S. Iycopersici & S. lycopersici & Solanum lycopersicum & Dominican Rep. \\
\hline 36 & FIP 129* & S. majusculum & S. majusculum T & Lathyrus maritimus & USA \\
\hline 37 & IBT 8223 & S. majusculum & Stemphylium sp. & Lathyrus maritimus & USA \\
\hline 38 & FIP 170 & S. sarciniforme & S. loti & Lotus corniculatus & USA \\
\hline 39 & FIP 238* & S. sarciniforme & Stemphylium sp. & Cicer arietinum & Iran \\
\hline 40 & IBT 8217* & S. sarciniforme & S. sarciniforme & Cicer arietinum & USA \\
\hline 41 & IBT 8221 & S. sarciniforme & S. sarciniforme & Cicer arietinum & Iran \\
\hline 42 & CBS 408.54* & S. solani & S. solani & Solanum lycopersicum & USA \\
\hline 43 & FIP 125 & S. solani & S. solani & Solanum lycopersicum & USA \\
\hline
\end{tabular}




\begin{tabular}{|c|c|c|c|c|c|}
\hline Analysis \# & ID \# ${ }^{\mathrm{a}}$ & New names ${ }^{b}$ & Original names $^{c}$ & Host & Origin \\
\hline 44 & FIP 137 & S. solani & S. solani & Coronilla sp. & - \\
\hline 45 & FIP 138 & S. solani & S. solani & Lupinus & USA \\
\hline 46 & BA 1399 & Stemphylium sp. 2 & Stemphylium sp. & Quercus sp. & Spain \\
\hline 47 & BA 2319 & Stemphylium sp. 2 & Stemphylium sp. & Malus sp. & USA \\
\hline 48 & BA 463 & Stemphylium sp. 2 & Stemphylium sp. & Prunus avium & Denmark \\
\hline 49 & BA 516 & Stemphylium sp. 2 & Stemphylium sp. & Prunus avium & Denmark \\
\hline 50 & BA 570 & Stemphylium sp. 2 & Stemphylium sp. & Prunus avium & Denmark \\
\hline 51 & BA 608 & Stemphylium sp. 2 & Stemphylium sp. & Prunus avium & Denmark \\
\hline 52 & FIP 026 & Stemphylium sp. 1 & Stemphylium sp. & Daucus carota & New Zealand \\
\hline 53 & FIP 035 & S. beticola & Stemphylium sp. & Spinacia oleracea & USA \\
\hline 54 & FIP 066 & Stemphylium sp. 1 & Stemphylium sp. & Pisum sativum & New Zealand \\
\hline 55 & FIP 083 & Stemphylium sp. 2 & Stemphylium sp. & Allium cepa & Mexico \\
\hline 56 & FIP 107 & Stemphylium sp. 1 & Stemphylium sp. & Medicago sativa & New Zealand \\
\hline 57 & FIP 110 & Stemphylium sp. 2 & Stemphylium sp. & Trifolium pratense & New Zealand \\
\hline 58 & FIP 113 & Stemphylium sp. 2 & Stemphylium sp. & Medicago sativa & New Zealand \\
\hline 59 & FIP 145 & Stemphylium sp. 2 & Stemphylium sp. & Malus sp. & New Zealand \\
\hline 60 & FIP 157 & S. botryosum & S. botryosum & Medicago sativa & USA \\
\hline 61 & FIP 163 & S. botryosum & S. botryosum & Medicago sativa & USA \\
\hline 62 & FIP 165 & Stemphylium sp. 2 & S. botryosum & - & - \\
\hline 63 & FIP 173 & S. botryosum & S. botryosum & Lupinus & USA \\
\hline 64 & FIP 178 & Stemphylium sp. 2 & Stemphylium sp. & Petroselinum crispum & USA \\
\hline 65 & FIP 179 & Stemphylium sp. 2 & Stemphylium sp. & Petroselinum crispum & USA \\
\hline 66 & FIP 180 & Stemphylium sp. 2 & Stemphylium sp. & Petroselinum crispum & USA \\
\hline 67 & FIP 181 & Stemphylium sp. 2 & Stemphylium sp. & Petroselinum crispum & USA \\
\hline 68 & FIP 182 & Stemphylium sp. 2 & Stemphylium sp. & Petroselinum crispum & USA \\
\hline 69 & FIP 222* & S. beticola & Stemphylium sp. & Lens culinaris & USA \\
\hline 70 & FIP $227^{*}$ & S. simmonsii & Stemphylium sp. & Trifolium pratense & USA \\
\hline 71 & FIP 230 & Stemphylium sp. 2 & Stemphylium sp. & Lens culinaris & USA \\
\hline 72 & FIP 242 & Stemphylium sp. 1 & Stemphylium sp. & Trifolium pratense & - \\
\hline 73 & FIP 289 & S. botryosum & S. botryosum & Allium fistulosum & France \\
\hline 74 & FIP 292 & S. botryosum & S. botryosum & Allium fistulosum & France \\
\hline 75 & IBT 10199 & Stemphylium sp. 2 & Stemphylium sp. & Citrus maxima & - \\
\hline 76 & IBT 8214 & Stemphylium sp. 2 & Stemphylium sp. & Trigonella foenum-graecum & Egypt \\
\hline 77 & IBT 8220 & Stemphylium sp. 2 & Stemphylium sp. & Pyrus sp. & Italy \\
\hline 78 & IBT 9032 & Stemphylium sp. 2 & Stemphylium sp. & Triticum aestivum & Denmark \\
\hline 79 & FIP 140 & S. trifolii & S. trifolii & Trifolium repens & - \\
\hline 80 & FIP 141 & S. trifolii & S. trifolii & Trifolium repens & Canada \\
\hline 81 & FIP 194 & S. trifolii & S. trifolii & Trifolium repens & - \\
\hline 82 & FIP 197 & S. trifolii & S. trifolii & Trifolium sp. & - \\
\hline 83 & FIP 241 & S. trifolii & Stemphylium sp. & Trifolium sp. & - \\
\hline 84 & CBS 715.68* & S. vesicarium & S. vesicarium & Pisum sativum & Canada \\
\hline 85 & FIP 057* & S. vesicarium & S. herbarum & Lathyrus odoratus & Netherlands \\
\hline 86 & IBT 7159 & S. vesicarium & Stemphylium sp. & Hordeum vulgare & Denmark \\
\hline 87 & IBT 7161 & S. vesicarium & Stemphylium sp. & Hordeum vulgare & Denmark \\
\hline
\end{tabular}


${ }^{a}$ Culture collections from where the strain originated. BA: Collection of Birgitte Andersen (part of the IBT collection); CBS: Centraalbureau voor Schimmelcultures, The Netherlands; IBT and FIP: Department of Bioengineering, Technical University of Denmark. *Strains also treated in Woudenberg et al. (2017). All known identification numbers for each strain can be found in supplementary material Table $\mathbf{S 1 .}$

${ }^{\mathrm{b}}$ New name corresponding to the morphological and chemical findings in this study and the phylogeny by Woudenberg et al. (2017). Stemphylium sp. 1 and 2 refer to the location in cluster 1 and 2, respectively, of the strain in Figure 1.

${ }^{\mathrm{c}}$ The original name/identity the culture arrived with from the culture collection. 
517 Table 2. Production of known metabolites and unknown species-specific metabolites by different

518 Stemphylium species ( $\mathrm{n}=$ number of strains). Clu 1 contains $S$. botryosum, S. eturmiunum and

519 Stemphylium sp1 strains and Clu 2 contains S. vesicarium (including S. alfalfae and S. herbarum) and

520 Stemphylium sp2 strains.

\begin{tabular}{|c|c|c|c|c|c|c|c|c|c|c|c|}
\hline Metabolite $^{\mathrm{a}}$ & $\begin{array}{c}\text { beti } \\
(n=2)\end{array}$ & $\begin{array}{c}\text { glob } \\
(n=5)\end{array}$ & $\begin{array}{c}\text { grac } \\
(n=5)\end{array}$ & $\begin{array}{l}\text { lanc } \\
(n=2)\end{array}$ & $\begin{array}{c}\text { loti } \\
(n=4)\end{array}$ & $\begin{array}{l}\text { maju } \\
(n=2)\end{array}$ & $\begin{array}{c}\text { sarc } \\
(n=4)\end{array}$ & $\begin{array}{c}\text { sola } \\
(n=4)\end{array}$ & $\begin{array}{c}\text { trif } \\
(n=5)\end{array}$ & $\begin{array}{c}\text { Clu } 1 \\
(n=20)\end{array}$ & $\begin{array}{c}\text { Clu } 2 \\
(n=29)\end{array}$ \\
\hline Alterporriol G/H & - & 5 & - & 1 & - & - & - & 4 & 4 & 8 & 12 \\
\hline Alterporriol I/J & - & - & - & - & - & - & - & 3 & - & - & 3 \\
\hline $\begin{array}{l}\text { Altersolanol A } \\
\text { (=Stemphylin) }\end{array}$ & - & 5 & 5 & 1 & - & 1 & - & 4 & 5 & 17 & 25 \\
\hline Altersolanol K/L & - & 5 & 3 & 1 & 4 & - & - & 4 & 4 & 14 & 15 \\
\hline Altersolanol M & - & 3 & - & - & - & - & - & 2 & - & 2 & 1 \\
\hline $\begin{array}{l}\text { Altertoxin II } \\
\text { (= stemphyltoxin II) }\end{array}$ & 1 & 4 & 5 & 1 & - & 2 & - & - & 1 & 17 & 28 \\
\hline Curvularin & - & - & - & - & - & - & - & - & - & 1 & 12 \\
\hline Dehydrocurvularin & - & - & - & - & - & - & - & - & - & 1 & 12 \\
\hline Macrosporin & - & 5 & 4 & 2 & - & - & & 4 & 5 & 15 & 19 \\
\hline Orobol & - & - & - & - & - & - & - & - & 5 & - & - \\
\hline Pyrenophorin & - & - & - & - & 4 & 1 & - & - & - & 7 & 1 \\
\hline Pyrenophorol & - & - & - & - & 4 & - & - & - & - & 2 & - \\
\hline Solanapyrone A & - & - & - & 2 & - & - & - & - & - & - & - \\
\hline Stemphol & 2 & 2 & 2 & - & 4 & 2 & 2 & 4 & - & 18 & 17 \\
\hline Stemphone & 1 & - & - & - & 1 & - & 4 & - & 5 & 4 & 7 \\
\hline Stemphyloxin I/II & - & - & - & - & - & - & - & - & 1 & 3 & 2 \\
\hline Stemphyltoxin I & 1 & 4 & 5 & 1 & - & - & - & - & - & 11 & 20 \\
\hline Stemphyltoxin III & 1 & 5 & 5 & 1 & - & 2 & - & - & 1 & 17 & 25 \\
\hline Stemphyperylenol & 2 & 5 & 5 & 1 & - & 2 & - & 1 & 5 & 20 & 28 \\
\hline Stemphypyrone & 2 & 5 & 5 & 2 & 4 & 2 & 4 & 4 & 5 & 20 & 29 \\
\hline Ukn095 & 2 & - & - & - & - & - & - & - & - & - & - \\
\hline Ukn185 ${ }^{b}$ & 2 & - & - & - & - & - & - & - & - & - & - \\
\hline Ukn212 & 2 & - & - & - & - & - & - & - & - & - & - \\
\hline Ukn074 & - & 5 & 5 & - & - & - & - & - & - & - & - \\
\hline Ukn094 & - & - & 5 & - & - & - & - & - & - & - & - \\
\hline Ukn287 & 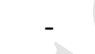 & - & 5 & - & 4 & - & - & - & - & - & - \\
\hline Ukn063 & - & - & - & - & 4 & - & - & - & - & - & - \\
\hline Ukn191 & - & - & - & 2 & 4 & 2 & - & - & - & - & - \\
\hline Ukn210 & - & - & - & 2 & - & - & - & - & - & - & - \\
\hline Ukn054 & - & - & - & - & - & - & - & - & 5 & - & - \\
\hline Ukn184 & - & - & - & - & - & - & 4 & - & 5 & - & - \\
\hline Ukn116 & - & - & - & - & - & - & 4 & - & - & - & - \\
\hline Ukn196 & - & - & - & - & - & - & - & 4 & - & - & - \\
\hline Ukn224 & - & - & - & - & - & - & - & - & - & - & 23 \\
\hline
\end{tabular}

${ }^{a}$ Metabolite identification are based on comparison of UV-spectrum and exact mass. 
$522{ }^{\mathrm{b}}$ Ukn185 and Ukn212 are identical to metabolites 1010 and 1120 in Andersen et al. 2009.

523 
524 Table 3. Retention time (RT), $m / z$ of the $[\mathrm{M}+\mathrm{H}]^{+}$adduct and a proposed molecular formula for the 525 unknown species specific Stemphylium metabolites given in Table 2.

\begin{tabular}{lrrl} 
Metabolite & RT (min) & Mass [M+H] & Putative formula \\
\hline Ukn095 & 4.7 & 205.086 & $\mathrm{C}_{12} \mathrm{H}_{12} \mathrm{O}_{3}$ \\
Ukn185 & 6.7 & 409.165 & $\mathrm{C}_{24} \mathrm{H}_{24} \mathrm{O}_{6}$ \\
Ukn212 & 7.4 & 409.165 & $\mathrm{C}_{24} \mathrm{H}_{24} \mathrm{O}_{6}$ \\
Ukn074 & 4.2 & 235.060 & $\mathrm{C}_{12} \mathrm{H}_{10} \mathrm{O}_{5}$ \\
Ukn094 & 4.7 & 319.227 & $\mathrm{C}_{20} \mathrm{H}_{30} \mathrm{O}_{3}$ \\
Ukn287 & 10.6 & 273.258 & $\mathrm{C}_{20} \mathrm{H}_{32}$ \\
Ukn063 & 3.9 & 184.097 & $\mathrm{C}_{9} \mathrm{H}_{13} \mathrm{NO}_{3}$ \\
Ukn191 & 6.8 & 375.180 & $\mathrm{C}_{21} \mathrm{H}_{26} \mathrm{O}_{6}$ \\
Ukn210 & 7.4 & 345.170 & $\mathrm{C}_{20} \mathrm{H}_{24} \mathrm{O}_{5}$ \\
Ukn054 & 3.8 & 286.155 & $\mathrm{C}_{16} \mathrm{H}_{19} \mathrm{~N}_{3} \mathrm{O}_{2}$ \\
Ukn184 & 6.7 & 471.274 & $\mathrm{C}_{28} \mathrm{H}_{38} \mathrm{O}_{6}$ \\
Ukn116 & 5.3 & 836.362 & $\mathrm{C}_{29} \mathrm{H}_{45} \mathrm{~N}_{19} \mathrm{O}_{11}$ \\
Ukn196 & 6.8 & 430.224 & $\mathrm{C}_{25} \mathrm{H}_{27} \mathrm{~N}_{5} \mathrm{O}_{2}$ \\
Ukn224 & 8 & 365.316 & $\mathrm{C}_{22} \mathrm{H}_{40} \mathrm{~N}_{2} \mathrm{O}_{2}$ \\
\hline
\end{tabular}


530 Fig. 1. Morphology of selected Stemphylium strains after 7 days of growth on SNA (A, B and C), PCA

531 (D, E and F) and V8 (G, H and I). A, D and G are Stemphylium sp. (\#76), B, E and H are S. sarciniforme $532(\# 40)$ and C, F and I are S. gracilariae (\#24). Scale bar is $50 \mu \mathrm{m}$.

534 Fig. 2. Morphology of selected Stemphylium strains after 7 days of growth on PCA. A: S. botryosum 535 (\#60), B: Stemphylium sp. 2 (\#62), C: S. botryosum (\#73), D: S. vesicarium (\#84), E: S. vesicarium (\#03), 536 F: S. vesicarium (\#85), G: S. simmonsii (\#70), H: S. eturmiunum (\#13) and I: S. globuliferum (\#19). Scale 537 bar is $50 \mu \mathrm{m}$.

539 Fig. 3. Dendrogram based on a cluster analysis of 87 Stemphylium strains and 219 known and 540 unknown metabolites. Strain labels: strain ID (analysis number-host) as given in Table 1. T: type 541 culture. *: ascomata produced on PCA. The dendrogram is calculated using the Yule correlation 542 coefficient and UPGMA as the clustering method and the axis shows the correlation coefficient. 


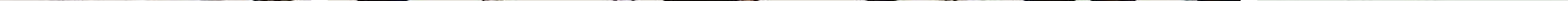


A $:$

"B $-5^{2}$

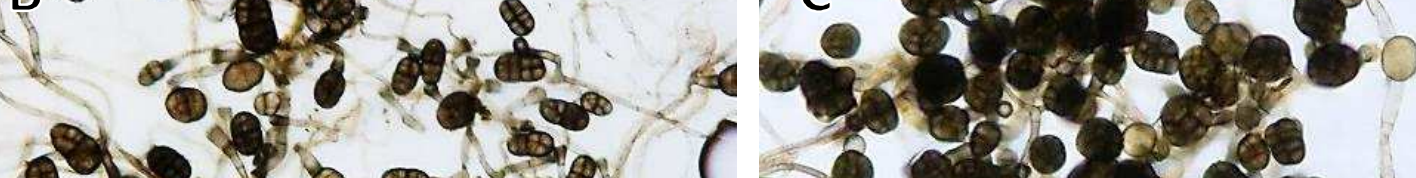

$c^{0} x^{2}+90$

20.10

- $0.108^{\circ}$

- 18 -

(D)

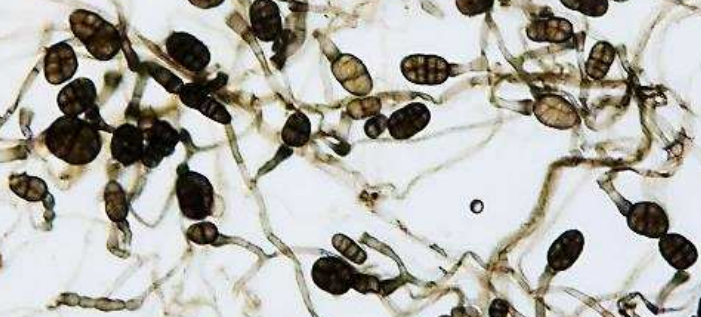

2)

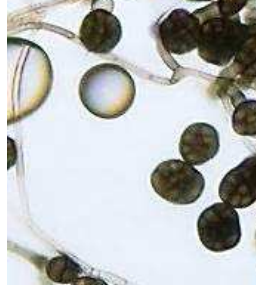

rol 30

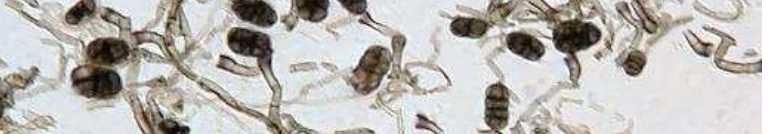

$\int_{0}^{-2 b^{2}}$

D $90 \% 0$ - a - á.

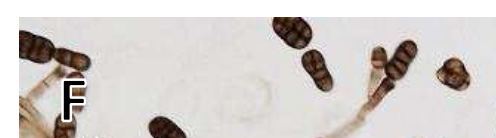

a. 198

(2)

$1 \%$

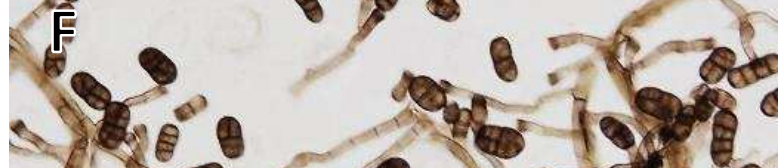

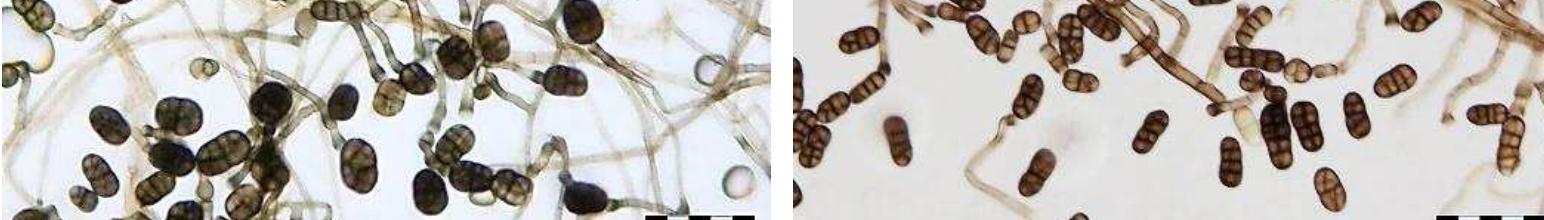

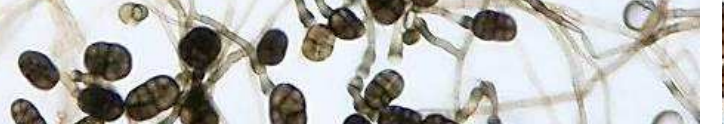

2. 4

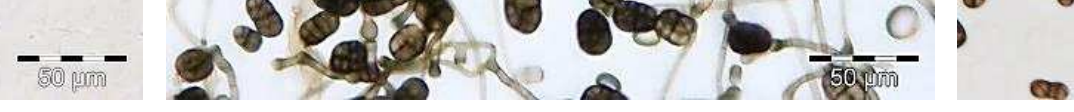

$$
\text { - } 1 .
$$

G. Ko.

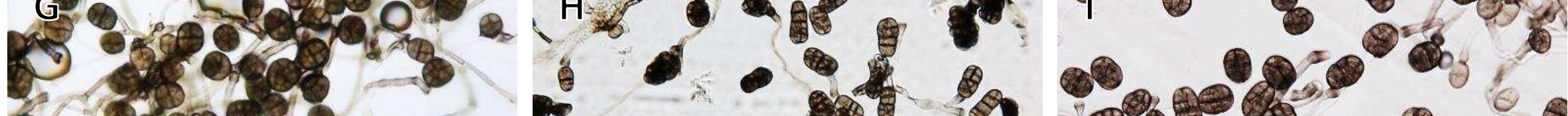

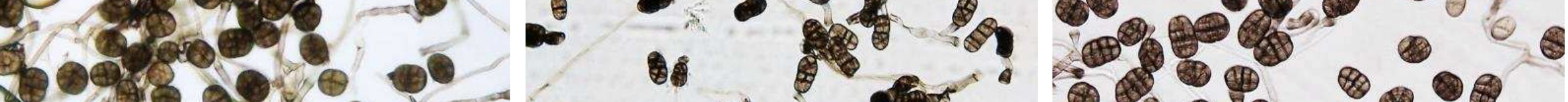
1. 


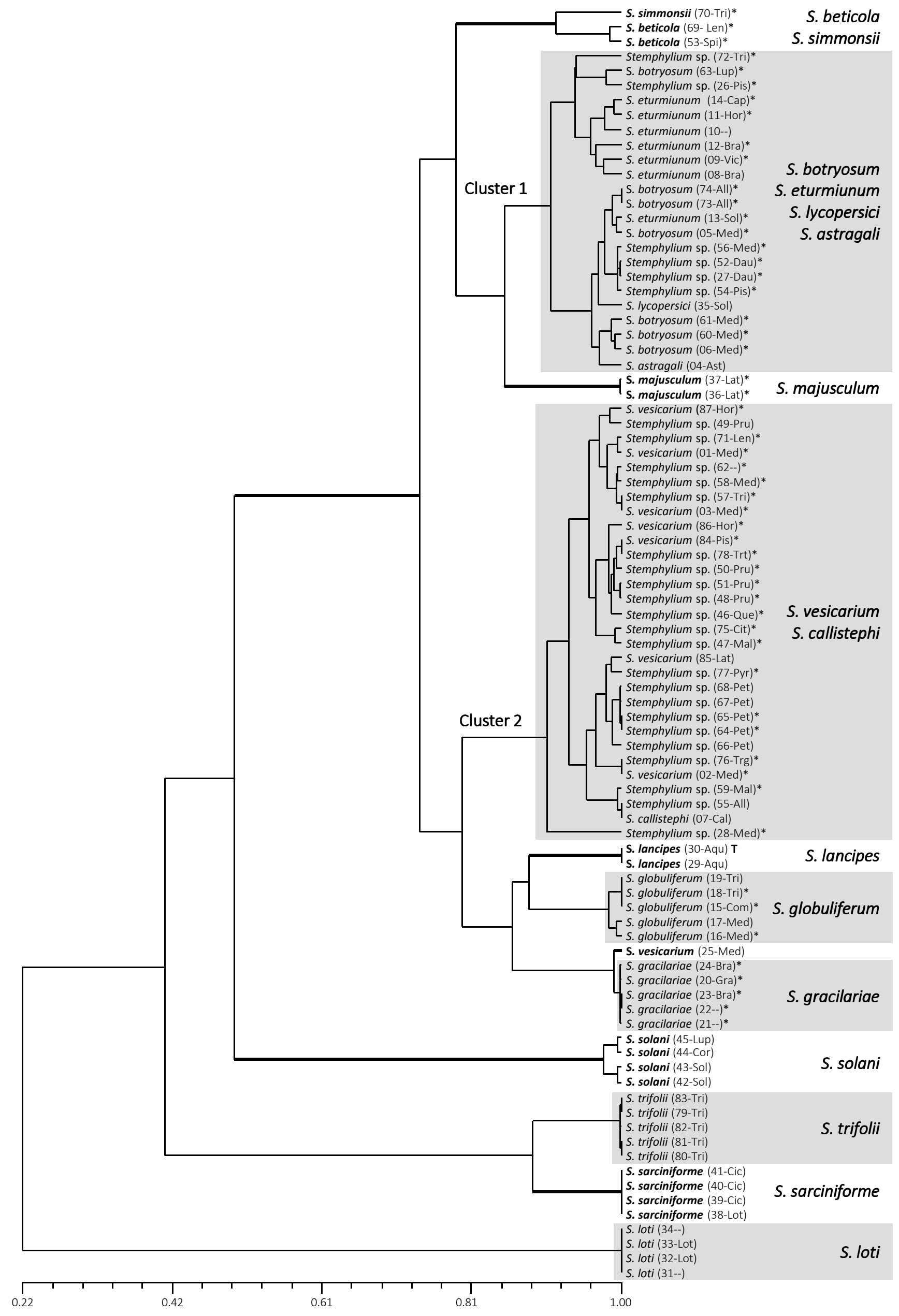

